\title{
Effects of habitat structure on the epifaunal community in Mussismilia corals: does coral morphology influence the richness and abundance of associated crustacean fauna?
}

\author{
Marcos M. Nogueira ${ }^{1} \cdot$ Elizabeth Neves $^{1} \cdot$ Rodrigo Johnsson $^{1}$
}

Received: 4 February 2014/Revised: 27 March 2015/Accepted: 10 April 2015/Published online: 24 April 2015

(C) Springer-Verlag Berlin Heidelberg and AWI 2015

\begin{abstract}
Coral habitat structures increase abundance and richness of organisms by providing niches, easy access to resources and refuge from predators. Corals harbor a great variety of animals; the variation in coral species morphology contributes to the heterogeneity and complexity of habitat types. In this report, we studied the richness and abundance of crustaceans (Decapoda, Copepoda, Peracarida and Ostracoda) associated with three species of Mussismilia exhibiting different growth morphologies, in two different coral reefs of the Bahia state (Caramuanas and Boipeba-Moreré, Brazil). Mussismilia hispida is a massive coral; $M$. braziliensis also has a massive growth pattern, but forms a crevice in the basal area of the corallum; $M$. harttii has a meandroid pattern. PERMANOVA analysis suggests significant differences in associated fauna richness among Mussismilia species, with higher values for M. harttii, followed by M. braziliensis and later by $M$. hispida. The same trend was observed for density, except that the comparison of M. braziliensis and M. hispida did not show differences. Redundancy and canonical correspondence analysis indicated that almost all of the crustacean species were more associated with the M. harttii
\end{abstract}

Communicated by L. Gimenez.

Electronic supplementary material The online version of this article (doi:10.1007/s10152-015-0431-x) contains supplementary material, which is available to authorized users.

Marcos M. Nogueira

mmouran@gmail.com

1 LABIMAR (Laboratório de Invertebrados Marinhos: Crustacea, Cnidaria e Fauna Associada), Depto. de Zoologia, Instituto de Biologia, Universidade Federal da Bahia, Rua Barão de Geremoabo, No. 147, Campus Ondina. CEP, Salvador, BA 40170-115, Brazil colonies that formed a group clearly separated from colonies of $M$. braziliensis and M. hispida. We also found that the internal volume of interpolyp space, only present in $M$. harttii, was the most important factor influencing richness and abundance of all analyzed orders of crustaceans.

Keywords Habitat complexity - Habitat heterogeneity · Scleractinian corals $\cdot$ Associated fauna

\section{Introduction}

Habitat structure can affect the distribution, abundance, richness and trophic relationships of species in different ecosystems (Beck 2000; Vytopil and Willis 2001; Grabowski 2004; Langellotto and Denno 2004; Tews et al. 2004; Grabowski et al. 2008). Habitat structure is defined as the variability and complexity of a system property $(\mathrm{Li}$ and Reynolds 1994). Despite the importance and recognition of the habitat structure effects on the community structure, there is no consensus about the definition and concepts of this structure. Tews et al. (2004) suggested that the different terms used are synonymous, and heterogeneity is the most common word used to describe habitat structure. However, some authors (August 1983; Downes et al. 1998; Beck 2000) disagreed with this statement and have adopted two axes or components of habitat structure: complexity and heterogeneity. The former is represented by the amount of physical structure, and the latter is represented by the addition of different types of physical elements to the system.

Habitats that are more complex and/or heterogeneous should increase species abundance and richness (MacArthur and MacArthur 1961; Vytopil and Willis 2001; Grabowski 2004; Langellotto and Denno 2004; Tews et al. 
2004; Grabowski et al. 2008). In different environments, the positive influence of habitat structure (complexity and heterogeneity) can be explained by providing more available niches (Bazzaz 1975; Vytopil and Willis 2001), increasing environmental diversity, increasing access to resources and reducing the effectiveness of predators (Menge and Sutherland 1976; Piko and Szedlmayer 2007).

Some studies have shown contradictory results, showing a decrease in species diversity with increase in habitat heterogeneity and/or complexity. Explanations for these findings include suggestions that different taxonomic groups may respond to different forms of the habitat structure and that the structural components and spatial scales evaluated may not be the most appropriate for the studied taxa (Tews et al. 2004). As a result, it is necessary to identify the effects of habitat structures in different taxa and the components of the habitat structures that influence these taxa.

Marine sessile organisms are used by small invertebrates as microhabitats (Kumagai 2008); different sessile species may provide different types of habitat complexity and heterogeneity. Several studies have identified such organisms hosting other organisms, e.g., sponges (Ribeiro et al. 2003), hydroids (Genzano 2001), gorgonians (Kumagai 2008) and zoanthids (Pérez et al. 2005); however, few studies have evaluated the importance of the habitat structure provided by such organisms (Vytopil and Willis 2001).

Scleractinian corals construct large carbonate structures that harbor a great variety of invertebrate species. The morphological patterns of coral growth may influence the associated fauna once the coral skeleton is available as habitat. Specific growth patterns may protect associated individuals or expose them to predators. The coral may provide food by trapping particulate material, mucus and tissue; it also provides shelter against environmental stressors (Carricart-Ganivet et al. 2004). Edwards and Emberton (1980) identified the effectiveness of protection against predators, provided by the branching coral
Stylophora pistillata, in colonies with higher openness in branches: Richness and abundance were lower than in tighter branch colonies where fish predators had access to prey upon associated crustaceans. Abele and Patton (1976) reported a positive correlation between coral head size with richness and abundance for the majority of the studied crustacean species. However, for species with territorial behavior, such as the shrimp Alpheus lottini, the size of the population did not depend on coral head size: In almost $80 \%$ of every coral head, a single male-female pair was found regardless of available space in coral head.

Over geological time, the increase in crustacean richness was positively influenced by the increase in the abundance of reefs (Klompmaker et al. 2013a). Also is recorded that the morphology of corals influences the patterns of richness and abundance of associated crustaceans, with a higher values near branching corals (Klompmaker et al. 2013b).

In the Brazilian coast, coral reefs occupy an extension of almost 2,000 km. However, despite the known importance of them, these environments are under an intense degradation process (accelerated urban center growth, tourist development, agricultural activities, mineral and chemical industries, oil exploration, increased sedimentation and the disposal of industrial and urban effluents). Six of the mainly reef-building corals are endemic, and four of these endemic species are related to a tertiary coral fauna. Three of these archaic species are the most common forms in almost all modern Brazilian reefs, and all of them belong to the genus Mussismilia (M. harttii, M. braziliensis and M. hispida) (Laborel 1970; Leão 1986; Leão et al. 2003). In this way, the aim of this study was to evaluate the effects of the habitat structures provided by coral species of the genus Mussismilia (Fig. 1). We tested whether there is significant difference on the richness and abundance of crustaceans, the most frequent and abundant group living associated with coral colonies (Nogueira 2003; Stella et al. 2011), and identified morphological characters (structural components) influencing them.
Fig. 1 Images showing the morphological pattern of Mussismilia species, and the systematic sampling scheme in which colonies were collected alternating the species and with at least $3 \mathrm{~m}$ of distance: a circle-Mussismilia harttii (UFBA 897); b square-M. braziliensis (UFBA891); and c triangle-M. hispida (UFBA 894)

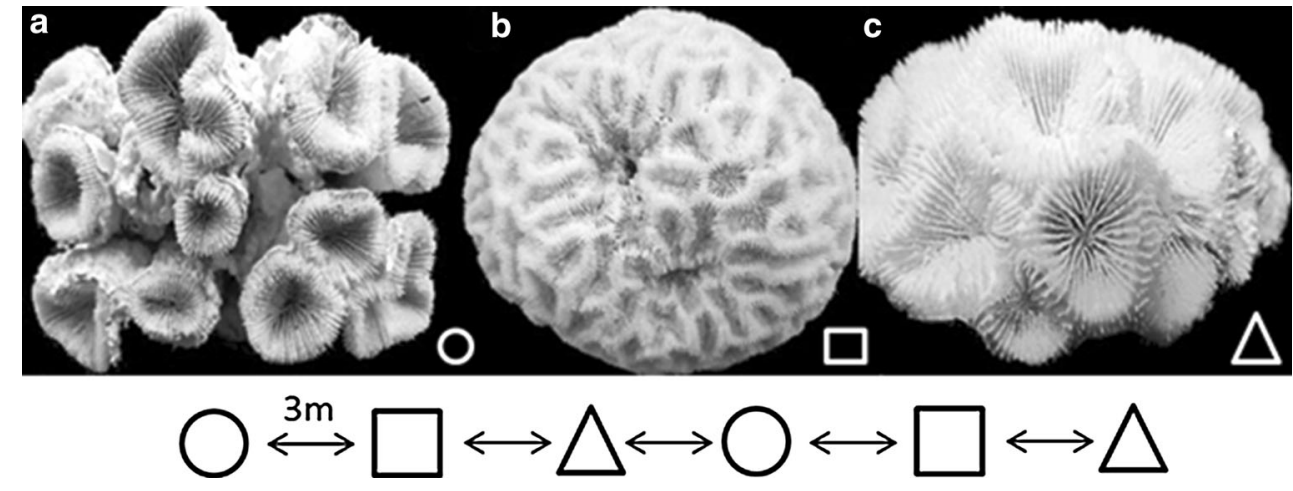




\section{Materials and methods}

The specimens analyzed were collected in February 2011 in two different coral reefs of the Bahia state, Brazil: Caramuanas $\left(13^{\circ} 07^{\prime} \mathrm{S}-38^{\circ} 43^{\prime} \mathrm{W}\right)$ and Boipeba-Moreré $\left(13^{\circ} 28^{\prime} \mathrm{S}-39^{\circ} 02^{\prime} \mathrm{W}\right)$. The former is located in Baía de Todos os Santos (BTS), the second largest coastal bay in Brazil with an area of approximately $1200 \mathrm{~km}^{2}$ (Cirano and Lessa 2007). Caramuanas belongs to the 'Todos os Santos Bay Environmental Protected Area,' which was established in 1999.

Caramuanas and Boipeba-Moreré were chosen as the sampling sites because they harbored all three species of Mussismilia endemic to Brazil. Caramuanas is a reef $4 \mathrm{~km}$ from the coastal shore with no common visitors except fisherman, and during the low tide, the top of the reef is exposed. Boipeba-Morere is a $432-\mathrm{km}^{2}$ reef located in the Tinharé-Boipeba Environmental Protected Area on the south shore area of Bahia. This reef is also exposed during low tide, but is commonly visited by tourists (Fig. 2).

The carcinofauna community was examined in colonies of three species of the extant Brazilian endemic genus Mussismilia: Mussismilia harttii, M. hispida and $M$. braziliensis. Each species shows a different morphological pattern that may influence the richness and abundance of associated fauna. Mussismilia hispida is a typically massive coral; M. braziliensis also has a massive growth pattern, but forms a crevice in the basal area of the corallum; $M$. harttii has a meandroid pattern in which polyps grow apart of each other, leaving space available for other organisms.

In both sites, ten samples of Mussismilia corals of each species were systematically collected on the reef flat (corals with diameter $<30 \mathrm{~cm}$ ). Samples were taken in stations distant $3 \mathrm{~m}$ within an area of approximately $100 \mathrm{~m}^{2}$. The

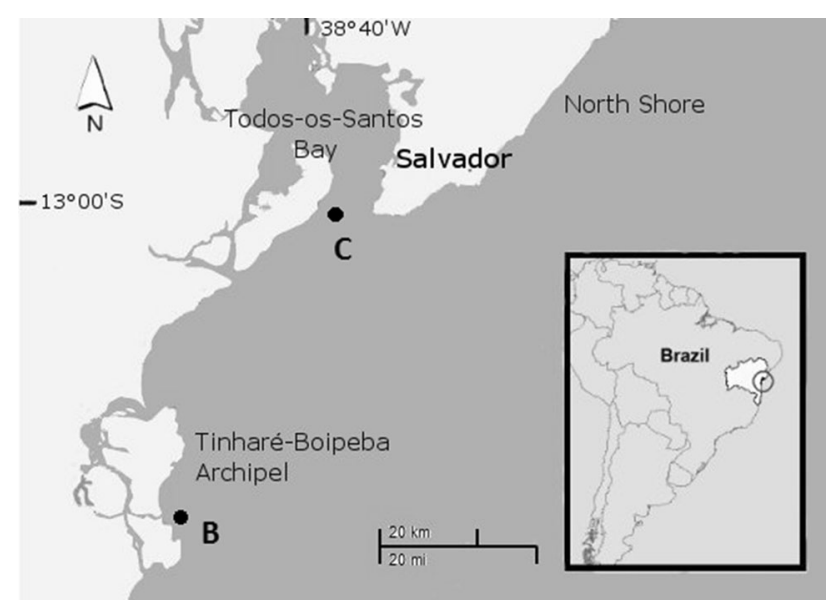

Fig. 2 Map of the Bahia shore showing the sampling areas. CCaramuanas and B-Boipeba (modified from Nogueira et al. 2014) same species was never collected consecutively (e.g., after sampling $M$. harttii, the following collected was $M$. braziliensis, and then M. hispida; Fig. 1). Samples were taken by free diving at depths varying from one to approximately $4 \mathrm{~m}$. Colonies were covered with plastic bags and then removed from the substratum using a hammer and chisel, and there was no visible escape during this process or divers approaching. After collection, the corals were washed and the water from the washing was filtered in a $150-\mu \mathrm{m}$ mesh, so organisms smaller than mesh size and crustacean larvae were not considered. The collected specimens were then stored in $70 \%$ alcohol. The crustaceans caught in the samples were identified and counted using stereomicroscopy. Corals and crustaceans are deposited in the UFBA museum collection. After identification, the number of crustaceans per coral colony diameter was calculated to use density as a measure of abundance.

\section{Structural components of the microhabitat provided by corals}

To evaluate the influence of coral morphology, colonies were bleached in a solution of $2.0 \%$ sodium hypochlorite. We counted the number of corallites (NC). For morphometric analyses, five corallites were chosen per colony to measure the mean diameter of corallites (DIMC), mean depth of columella (PC), mean distance among corallites (DISTMC) and mean number of septa (NSEP), using MITUTOYO (0.01-150; $0.02 \mathrm{~mm}$-error range) digital calipers. We also measured mean corallites height (ALP) (only in M. harttii), the area of the crevice at the colony base (VSI) (only in M. braziliensis) and the internal volume of interpolyp space (VIC): For the latter variable, colonies were coated and the space between the polyps was filled with sieved sediment in $150-\mu \mathrm{m}$ mesh.

Mussismilia corals provided a number of different structural components. $M$. harttii presented seven components (number of corallites, the mean diameter of corallites, mean depth of columella, mean distance among corallites, mean number of septa, mean corallites height and the internal volume of interpolyp space), M. braziliensis presented six components (number of corallites, the mean diameter of corallites, mean depth of columella, mean distance among corallites, mean number of septa and the area of crevice at the colony base), and M. hispida presented five components (number of corallites, the mean diameter of corallites, mean depth of columella, mean distance among corallites and mean number of septa).

\section{Data analysis}

The richness and density of the crustaceans associated with Mussismilia species were transformed $(\log \mathrm{x}+1$, base 10$)$. 
PERMANOVA was applied to identify the differences in richness and density in response to Mussismilia species. This is a univariate or multivariate analysis of variance using permutation procedures to obtain $p$ values. This method is suitable for any multifactorial ANOVA design, allowing for all pairwise multiple comparisons by permutation. We used the Bray-Curtis measure of dissimilarity with 9999 permutations per test (Anderson 2001).

Community-level responses to coral morphological variables were evaluated through gradient analysis techniques. According to Leps and Smilauer (1999), it is crucial to verify the length of the environmental gradient to be able to choose between either canonical correspondence analysis (CCA) or redundancy analysis (RDA). This can be achieved performing the detrended canonical correspondence analysis (DCCA). If results provide a number $<3$, we must perform a RDA, whereas $>3$ values indicate that we should perform a CCA, such analysis was performed using the CANOCO version 4.5.

As Decapoda achieved a length of 3.354, a CCA was performed. For all other crustacean groups analyzed, a RDA was carried out because of the gradient length $($ Copepoda $=1.107 ; \quad$ Peracarida $=1.613 ; \quad$ Ostraco$\mathrm{da}=1.368)($ Leps and Smilauer 1999). The influence of the coral measurements was analyzed singly for each group, supported by previous information about different structural components that may influence groups associated with the habitat in different ways that are sometimes species specific (Beck 2000; Tews et al. 2004).

The results of CCA and RDA analyses were drawn on triplots with associated species; corals in study and coral parameters were represented as vectors. Species data were transformed to $\log (\mathrm{x}+1)$, and the coral measurements were transformed to square roots. Collinearity between the coral variables was evaluated (CRM values higher than 0.7 ), and because of this, some of the variables were removed to perform the analysis: mean depth of columella (PC); number of corallites (NC); and the mean corallites height (ALP).

\section{Results}

\section{Associated fauna characterization}

A total of 12,554 crustaceans were collected in association with Mussismilia corals from both sites. The most abundant were Copepoda (Caramuanas: $n=2740$, Boipeba: $n=$ 3994), followed by Peracarida (Caramuanas: $n=1817$, Boipeba $n=2949$ ), Ostracoda (Caramuanas: $n=705$, Boipeba: $n=926$ ) and Decapoda (Caramuanas: $n=182$, Boipeba: $n=91$; Fig. 3 ).

We found significant differences in the richness of fauna associated with Mussismilia corals (PERMANOVA

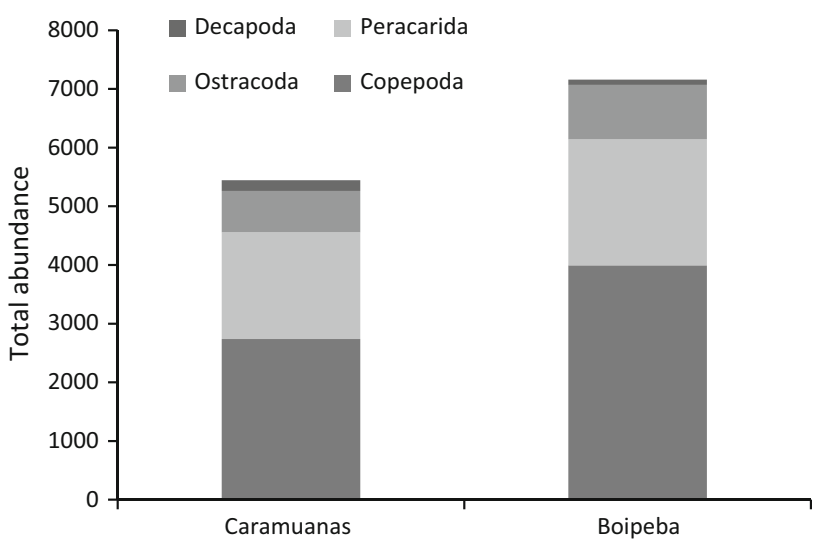

Fig. 3 Total individual number of major crustacean taxa collected

$p=0.0001 ; F=24.9257)$, but richness did not vary between sites ( $p=0.1079 ; F=2.2960)$. Pairwise, a posteriori comparisons indicated that $M$. harttii harbored a richer fauna than $M$. braziliensis $(p=0.0001)$ and $M$. hispida ( $p=0.0001) ;$ M. braziliensis also showed higher richness than $M$. hispida $(p=0.0032)$. The same pattern can be visualized for both areas (Fig. 4).

Faunal density varied among corals (Fig. 4) (PERMANOVA: $p=0.0001 ; F=10.5571)$ and between sites $(p=0.0185 ; F=3.7643)$. Density was higher in $M$. harttii than $M$. braziliensis $(p=0.0001)$ and $M$. hispida $(p=0.0001)$. However, we did not find differences of density between $M$. braziliensis and $M$. hispida $(p=0.2045)$.

For Decapoda, CCA showed that coral features explained $98.8 \%$ of species variation assemblage. The first two axes together accounted for $75.6 \%$ of the variance. All canonical axes were also determined to be significant using the Monte Carlo permutation test ( $p=0.002 ; F=2.888$, Table 1).

On the CCA plot, coral samples of $M$. harttii (1 and 4) from both areas formed a group mainly toward negative values of the Axis I; toward the positive values, samples of M. braziliensis (2 and 5) and M. hispida (3 and 6) clustered. This was consistent with the absence of significant differences in the PERMANOVA on individual density. The CCA plot also revealed that almost all coral features included in the analysis reached higher values in M. harttii, with internal volume of interpolyp space and mean number of septa showing a strong positive influence on most decapod species. Petrolisthes rosariensis, P. amoenus, $P$. galathinus, Pachicheles greeley, Mithraculus forceps, Mithrax verrucosus, Teleophrys pococki, Gartiope barbadensis, Pilumnos dassypodus, Synalpheus towsendi, Synalpheus sp., Alpheidae and Diogenidae were more associated with colonies of $M$. harttii. The species Hexapanopeus angustifrons and Troglocarcinus sp. were more associated with colonies of $M$. braziliensis and M. hispida 
Fig. 4 Mean richness and density (Ind. $/ \mathrm{cm}^{2}$ ) of crustaceans associated with Mussismilia species. MHAMussismilia harttii, $\mathrm{MB}-M$. braziliensis, MH-M. hispida

Table 1 Results of canonical correspondence analysis (CCA) for Decapoda and redundancy analysis (RDA) for Copepoda, Peracarida and Ostracoda
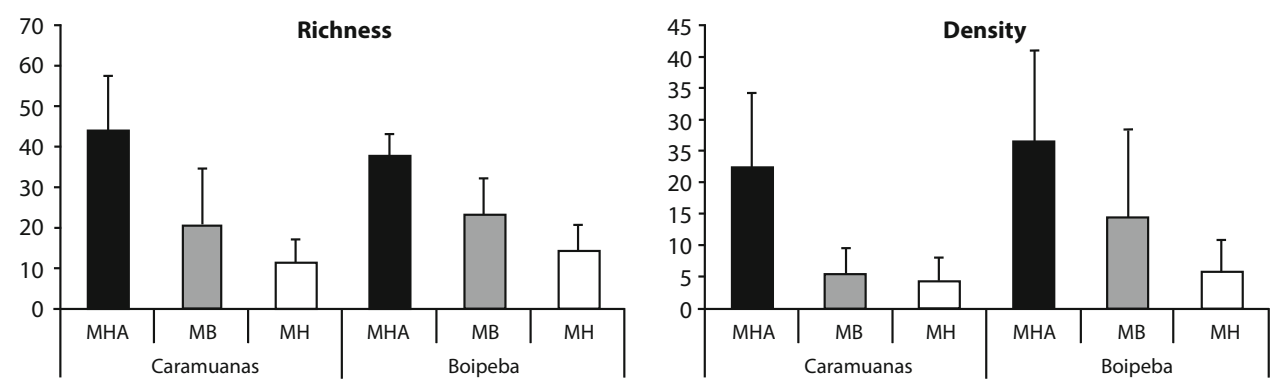

\begin{tabular}{|c|c|c|c|c|c|}
\hline \multicolumn{6}{|l|}{ Decapoda } \\
\hline Axes & 1 & 2 & 3 & 4 & Total inertia \\
\hline Eigenvalues & 0.452 & 0.355 & 0.171 & 0.076 & 4.099 \\
\hline Species-environment correlations & 0.805 & 0.773 & 0.667 & 0.480 & \\
\hline \multicolumn{6}{|l|}{ Cumulative percentage variance } \\
\hline of species data & 11.0 & 19.7 & 23.9 & 25.7 & \\
\hline of species-environment relation & 42.4 & 75.6 & 91.6 & 98.8 & \\
\hline Sum of all eigenvalues & & & & & 4.099 \\
\hline Sum of all canonical eigenvalues & & & & & 1.068 \\
\hline \multicolumn{6}{|l|}{ Copepoda } \\
\hline Axes & 1 & 2 & 3 & 4 & Total variance \\
\hline Eigenvalues & 0.247 & 0.050 & 0.012 & 0.006 & 1.000 \\
\hline Species-environment correlations & 0.802 & 0.637 & 0.555 & 0.385 & \\
\hline \multicolumn{6}{|l|}{ Cumulative percentage variance } \\
\hline of species data & 24.7 & 29.7 & 30.8 & 31.4 & \\
\hline of species-environment relation & 77.8 & 93.5 & 97.2 & 99.1 & \\
\hline Sum of all eigenvalues & & & & & 1.000 \\
\hline Sum of all canonical eigenvalues & & & & & 0.317 \\
\hline \multicolumn{6}{|l|}{ Peracarida } \\
\hline Axes & 1 & 2 & 3 & 4 & Total variance \\
\hline Eigenvalues & 0.123 & 0.052 & 0.018 & 0.007 & 1.000 \\
\hline Species-environment correlations & 0.778 & 0.679 & 0.647 & 0.369 & \\
\hline \multicolumn{6}{|l|}{ Cumulative percentage variance } \\
\hline of species data & 12.3 & 17.4 & 19.2 & 19.9 & \\
\hline of species-environment relation & 60.6 & 86.2 & 94.9 & 98.5 & \\
\hline Sum of all eigenvalues & & & & & 1.000 \\
\hline Sum of all canonical eigenvalues & & & & & 0.202 \\
\hline \multicolumn{6}{|l|}{ Ostracoda } \\
\hline Axes & 1 & 2 & 3 & 4 & Total variance \\
\hline Eigenvalues & 0.108 & 0.053 & 0.020 & 0.012 & 1.000 \\
\hline Species-environment correlations & 0.756 & 0.604 & 0.506 & 0.430 & \\
\hline \multicolumn{6}{|l|}{ Cumulative percentage variance } \\
\hline of species data & 10.8 & 16.0 & 18.1 & 19.3 & \\
\hline of species-environment relation & 53.3 & 79.4 & 89.5 & 95.6 & \\
\hline Sum of all eigenvalues & & & & & 1.000 \\
\hline Sum of all canonical eigenvalues & & & & & 0.202 \\
\hline
\end{tabular}

(Fig. 5a). Mitraculus forceps was the most abundant, followed by Mithrax verrucosus, Troglocarcinus sp. and Synalpheus towsendi (Fig. 6).

For copepods (RDA), $99.1 \%$ variation in the assemblage was explained by coral features: The first two axes explained $93.5 \%$ of the total variance (Table 1). The most 

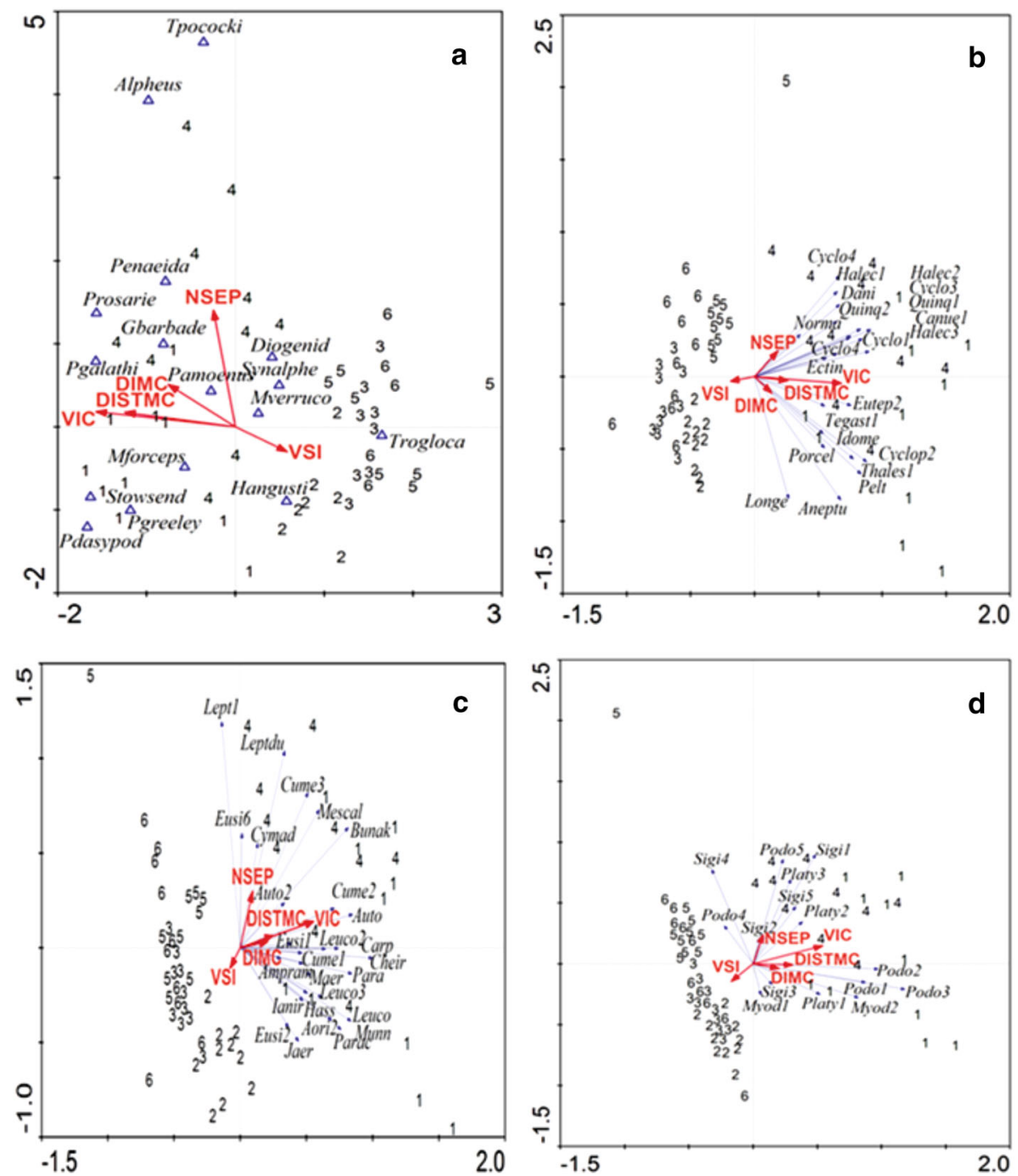

Fig. 5 a CCA for Decapoda and RDA for: b Copepoda, $\mathbf{c}$ Peracarida and d Ostracoda. NSEP-mean number of septa; DIMC-mean diameter of corallites; DISTMC-mean distance among corallites; VIC — internal volume of interpolyp space; VSI-area of crevice at colony base. Corals are represented by numbers: $1-M$. harttii at Caramuanas and 4 at Boipeba; $2-M$. braziliensis at Caramuanas and 5 at Boipeba; and 3-M. hispida at Caramuanas and 6 at Boipeba. Decapods are represented by triangles: Petrolisthes rosariensis (Prosarie), P. amoenus (Pamoenus), P. galathinus (Pgalathi), Pachicheles greeley (Pgreeley), Mithraculus forceps (Mforceps), Teleophrys pococki (Tpococki), Gartiope barbadensis (Gbarbade), Pilumnus dassypodus (Pdasypod), Synalpheus towsendi (Stowsend), Synalpheus sp. (Synalphe), Alpheidae (Alpheus), Diogenidae (Diogenid), Hexapanopeus angustifrons (Hangusti), Troglocarcinus hirsutus (Trogloca) and Mithrax verrucosus (Mverruco). Copepoda: Cyclopidae 4 (Cyclo4), Halectinosoma sp.1 (Halec1), Danielsseniidae (Dani), Quinquelaophonte sp.2 (Quinq2), Normanella sp. (Norma), Ectinosoma sp. (Ectino), Euterpinidae 2 (Eutep), Tegastes sp.1 (Tegast1), Idomene sp. (Idome), Porcellidium sp. (Porcel),

Cyclopidae 2 (Cyclop2), Halectinosoma 2 (Halec2), Cyclopidae 3 (Cyclop3), Quinquelaophonte 3 (Quinq3), Canuelidae 1 (Canue1), Halectinosoma 3 (Halec3) and Asterocheres neptunei (Aneptu). Peracarida: Leptochelida dubia (Leptdu), Leptochelia sp. (Lept1), Cumella sp.3 (Cume3), Eusiroidea 6 (Eusi6), Cymadusa sp. (Cymad), Mesanthura callicera (Mescal), Bunakenia (Extensibasella) sudvestatlantica (Bunak), Autonoe sp.1 (Auto), Eusiroidea 1 (Eusi1), Leucothoe sp.2 (Leuco2), Cumella sp.1 (Cume1), Cheiriphotis megacheles (Cheir), Carpias sp. (Carp), Ampithoe ramondi (Ampram), Maera sp. (Maer), Paranthuridae (Para), Leucothoe sp.3 (Leuco3), Ianiropsis sp. (Ianir), Hassenium occidentalis (Hass), Leucothoe sp.1 (Leuco), Eusiroidea 2 (Eusi2), Aoridae (Aori2), Munna sp. (Munn), Paracerceis sculpta (Parac) and Jaeropsis aff. dubia. Ostracoda: Sigilliocopina 1 (Sigi1), Sigilliocopina 2 (Sigi2), Sigilliocopina 3 (Sigi3), Sigilliocopina 4 (Sigi4), Sigilliocopina 5 (Sigi5), Podocopida 1 (Podo1), Podocopida 2 (Podo2), Podocopida 3 (Podo3), Podocopida 4 (Podo4), Podocopida 5 (Podo5), Platycopida 2 (Platy2), Platycopida 3 (Platy3), Myodocopida 1 (Myod1) and Myodocopida 2 (Myod2)

abundant species were Halectinosoma sp.1, Halectinosoma sp.2 and Quinquelaophonte sp.1 (Fig. 6). For peracarids, coral features explained $98.5 \%$ of the variation $(86.2 \%$

was explained by the two first axes); the most abundant species were Leptochelia dubia, Bunakenia (Extensibasella) sudvestatlantica and Cheiriphotis megacheles (Fig. 6). 
Fig. 6 Mean density (Ind./ $/ \mathrm{cm}^{2}$ ) of the most abundant species of major crustacean taxa associated with Mussismilia species. C-Caramuanas, BBoipeba, MHA-Mussismilia harttii, $\mathrm{MB}-M$. braziliensi and $\mathrm{MH}-M$. hispida
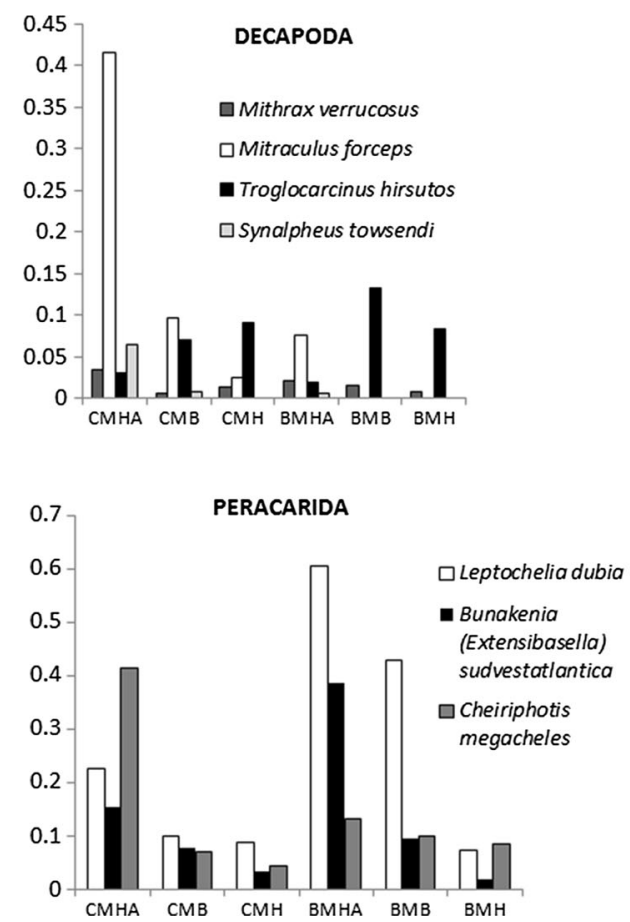
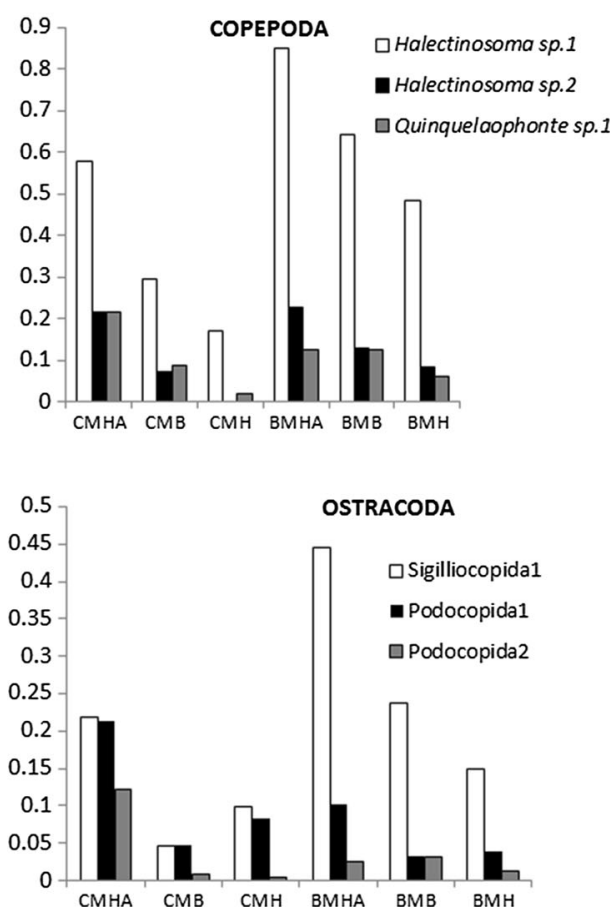

High values were also recorded for ostracods, as coral features explained $95.6 \%$ of variation in species, with the two first axes explaining $79.4 \%$ of species data variation; the most abundant organisms were Sigilliocopina 1, Podocopida 1 and Podocopida 2. For almost all these species, we recorded higher-density values associated with colonies of $M$. harttii, followed by $M$. braziliensis and finally $M$. hispida. Exceptions to this were Troglocarcinus sp., with higher values in colonies of $M$. hispida at Caramuanas and in M. braziliensis at Moreré, and Podocopida 2 that showed slightly higher values in $M$. brazilienis at Moreré (Fig. 6).

All plots of RDA (Copepoda: Fig. 5b, Peracarida: Fig. 5c and Ostracoda: Fig. 5d) showed two different groups; the first formed by the samples collected in $M$. harttii and the second group composed of samples of $M$. braziliensis and M. hispida in both sites. Almost all species of different groups were more associated with $M$. harttii; only the ostracods Podocopida 4 and Sigilliocopina 4 were recorded as being mainly associated with $M$. braziliensis and $M$. hispida. The internal volume of interpolyp space was identified as the most important coral feature structuring the composition of the associated fauna.

\section{Discussion}

Richness of crustaceans associated with Mussismilia corals was highest for M. harttii, followed by M. braziliensis, and M. hispida. This was observed consistently in both sites.
For density, Fig. 5 indicates the same trend of richness in Moreré reef; however, this difference was not apparent in the Caramuanas reef, where densities did not significantly differ between $M$. braziliensis and M. hispida. These patterns were found in both areas and indicate that the influence of the investigated Mussismilia corals is consistent. The consistent patterns found are in agreement with previous studies that examined the effects of habitat structure at different sites and times (Beck 2000).

Except by obligatory associates or host-specific organisms, associated fauna may select their host based on the protection provided of the morphological structure rather than on other effects, such as host chemical defenses (Henkel and Pawlik 2005). Thus, the primary reason for coral use may be its role as a habitat, as found by Stella et al. (2011). According to Coles (1980), coral skeletons provide protective habitats that effectively exclude predators and our results suggest that specific skeletal morphological features may act as key factors in this sheltering ability, providing refuge mainly from fish predators. In this way, the number of species and individuals associated with Mussismilia corals may be a product of different morphological patterns rather than differences in protection capacity of Mussismilia through the chemical defenses. This phenomenon is also supported by the fact that the evaluated corals are closely phylogenetically related, belonging to the same genus, which may be an indication for similar trends in chemical defenses. However, to verify this claim, studies evaluating the toxic potential of each species are necessary. As a result, structural components provided by corals may 
be the main factor influencing occupation by associated fauna.

As mentioned before, Mussismilia harttii presented 7 structural components, $M$. braziliensis presented 6 , and $M$. hispida presented 5. Following this, M. harttii represents a more heterogeneous habitat for associated fauna that is also seemingly more complex when compared to that of $M$. braziliensis and $M$. hispida. This is illustrated by the direction of the vectors in the triplot figures of RDA and CCA, representing the habitat variables: High values of almost all structural components are associated with $M$. harttii. Patterns of richness and density may be affected by specific structural components independently of the effects of complexity (Beck 2000). Despite higher values for almost all coral features measured in $M$. harttii, the nature of the structural component seems to be a more important factor influencing the community living on the coral than the number of structures. The most important structural component identified by RDA and CCA analysis was the internal volume of interpolyp space, exclusive of $M$. harttii colonies: The internal volume of interpolyp space may represent the most important morphological feature because of its effectiveness providing refuges against predators. Vytopil and Willis (2001) evaluated the associated fauna of Acropora species, a genus of branching corals, and identified the effect of space between branches: Crabs selected coral host according to the branch space. In addition, for $M$. braziliensis, the presence of the area of the crevice at the colony base showed an important role in sheltering associated fauna when compared to M. hispida, especially for decapods that can be easily seen hiding in the crevice of $M$. braziliensis.

Mussismilia harttii was identified as hosting higher richness and abundance of crustaceans when compared to corals that present massive growth (M. hispida and Siderastrea stellata) in a previous study (Young 1986). However, no statistical analysis was performed to evaluate these differences. The author identified a positive correlation of $M$. harttii volume with the number and abundance of associated species; however, the methods used by the author for measuring the coral volume (volume of water displaced in a receptacle by the introduction of coral) may not correctly quantify suitable space for associated fauna as it only indicates the space occupied by coral skeleton. We propose an alternative method to estimate the structural components that influence the associated fauna through the measurement of the volume of the space between corallites (VIC), which was identified as the most important factor influencing the patterns of the associated community. The role of the VIC seems to be so important that in bigger colonies of $M$. harttii, many species of Synalpheus (Alpheidae), a genus of commensal shrimps showing territorial behavior, were found to be living simultaneously in the same colony (Young 1986). In the present study, we limited the size of colonies collected to a diameter $<30 \mathrm{~cm}$. Nevertheless, we recorded the presence of two Synalpheus species living in the same $M$. harttii colony, S. brevicarpus and Synalpheus sp., at Caramuanas reef. Other studies dealing with associated crustacean fauna of corals identified only a male-female pair of alpheids (Alpheus) in colonies of the branching coral Pocillopora damicornis (Abele and Patton 1976).

Among the decapod species associated with Mussismilia corals, Mithraculus forceps was the most abundant, especially in colonies of M. harttii. Stachowicz and Hay (1999) identified a mutualistic association between this crab and the branching coral Oculina arbuscula, in which the crab relies on coral branches for food (consuming lipid-rich mucus) and protection, while the crab protects the host from being overgrown by algae with harmful chemicals that are commonly avoided by herbivores. Mithraculus forceps appears to have the same mutualistic association with the Brazilian coral $M$. harttii, living in the spaces among coral polyps and consuming algae surrounding the coral colony as seen in our field observations. Other important decapod species were associated with M. harttii: As in Young (1986), porcellanid crabs (Petrolisthes rosariensis and P. galathinus) are the most abundant species in $M$. harttii colonies.

Troglocarcinus hirsutus, species of the family Cryptochiridae, was one of the few species with low densities in colonies of $M$. hartti, but this may be related to differences in how these species use the corals. These crabs settle, as megalopa on a host colony, modify the patterns of calcium deposition during coral growth, and produce depressions or dome-like cavities through alimentary mechanisms and movements (Carricart-Ganivet et al. 2004). Canário et al. (2014) identified higher abundances of T. hirsutus associated with $M$. braziliensis, followed by $M$. hispida, and less number of crabs were recorded in $M$. harttii colonies. They suggest that the discrepancies in infestation values are related to particular skeleton traits. Thus, as corallites of $M$. harttii grow away from one to another, massive corals are more likely to guarantee habitat for the establishment of cryptochirid crabs.

In synthesis, our results indicate that the different coral morphologies of the endemic Mussismilia species represent different levels of habitat structure, with $M$. harttii representing the species harboring the richer and more abundant associated crustacean fauna. We also identified that a particular structural component may play an important role in the community structure of the associated fauna, as was recorded for the VIC. Manipulative studies, such as the exclusion of predators, should be performed to evaluate the effectiveness of the morphological pattern provided by Mussismilia species in harboring a more rich and abundant fauna. 
Acknowledgments We would like to thank the Coordenação de Aperfeiçoamento de Pessoal de Nível Superior (CAPES), Fundação de Amparo à Pesquisa no Estado da Bahia (FAPESB) and Post Graduation Course in Animal Diversity (PPGDA) for financial support, and Professor Francisco Barros for advices and material support.

\section{References}

Abele LG, Patton WK (1976) The size of coral heads and the community biology of associated decapod crustaceans. J Biogeogr 3:35-47

Anderson MJ (2001) A new method for non-parametric multivariate analysis of variance. Austral Ecol 26:32-46

August PV (1983) The role of habitat complexity and heterogeneity in structuring tropical mammal communities. Ecology 64(6): 1495-1507

Bazzaz FA (1975) Plant species diversity in old field successional ecosystems in southern Illinois. Ecology 56:485-488

Beck MW (2000) Separating the elements of habitat structure: independent effects of habitat complexity and structural components on rocky intertidal gastropods. J Exp Mar Biol Ecol 249:29-49

Canário R, Badaró MFS, Johnsson R, Neves EG (2014) A new species of Troglocarcinus (Decapoda: Brachyura: Cryptochiridae) symbiotic with the Brazilian endemic coral Mussismilia (Anthozoa: Scleractinia: Mussidae). Mar Biol Res 10:1-10

Carricart-Ganivet JP, Carrera-Parra LF, Quan-Young LI, GarcíaMadrigal MS (2004) Ecological note on Troglocarcinus corallicola (Brachyura: Cryptochiridae) living in symbiosis with Manicina areolata (Cnidaria: Scleractinia) in the Mexican Caribbean. Coral Reefs 23:215-217

Cirano M, Lessa GC (2007) Oceanographic characteristics of Baía de Todos os Santos, Brazil. Rev Bras Geof 25:363-387

Coles SL (1980) Species diversity of decapods associated with living and dead reef coral Pocilopora meandrina. Mar Ecol Prog Ser 2:281-291

Downes BJ, Lake PS, Schreiber ESG, Glaister A (1998) Habitat structure and regulation of local species diversity in a stony, upland stream. Ecol Monogr 68(2):237-257

Edwards AJ, Emberton HJ (1980) Crustacea associated with the scleractinian coral, Stylophora pistillata (Esper), in the Sudanese Red Sea. J Exp Mar Biol Ecol 42:225-240

Genzano G (2001) Associated fauna and sediment trapped by colonies of Tubularia crocea (Cnidaria, Hydrozoa) from the rocky intertidal of Mar del Plata, Argentina. Biociências 9:105-119

Grabowski JH (2004) Habitat complexity disrupts predator-prey interactions but not the trophic cascade on oyster reefs. Ecology 85(4):995-1004

Grabowski JH, Hughes AR, Kimbro DL (2008) Habitat complexity influences cascading effects of multiple predators. Ecology 89(12):3413-3422

Henkel TP, Pawlik JR (2005) Habitat use by sponge-dwelling brittlestars. Mar Biol 146:301-313

Klompmaker AA, Schweitzer CE, Feldmann RM, Kowalewski M (2013a) The influence of reefs on the rise of Mesozoic marine crustaceans. Geology 41(11):1179-1182

Klompmaker AA, Ortiz JD, Wells NA (2013b) How to explain a decapod crustacean diversity hotspot in a mid-Cretaceous coral reef. Palaeogeogr Palaeoclimatol 374:256-273
Kumagai NH (2008) Role of food source and predator avoidance in habitat specialization by an octocoral-associated amphipod. Oecologia 155:739-749

Laborel J (1970) Madréporaires et hydrocoralliaires récifaux dês côtes brésiliennes. systématique, écologie, répartition vertical et géographique. Ann Inst Oceanogr 47:15-229

Langellotto GA, Denno RF (2004) Responses of invertebrate natural enemies to complex-structured habitats: a meta-analytical synthesis. Oecologia 139:1-10

Leão ZMAN (1986) Guia para a identificação dos corais do Brasil. Universidade Federal da Bahia, Programa de Pesquisa e PósGraduação em Geofísica, Salvador, p 57

Leão ZMAN, Kikuchi RKP, Testa V (2003) Coral reefs of Brazil. In: Cortés Jorge (ed) Latin America coral reefs. Elsevier Science, Amsterdam, pp 9-52

Leps J, Smilauer P (1999) Multivariate analysis of ecological data. Faculty of Biological Sciences. University of South Bohemia, Ceské Budejovice, p 110

Li H, Reynolds JF (1994) Simulation experiment to quantify spatial heterogeneity in categorical maps. Ecology 75(8):2446-2455

MacArthur RH, MacArthur JW (1961) On bird species diversity. Ecology 42:594-598

Menge BA, Sutherland JP (1976) Species diversity gradients: synthesis of the roles of predation, competition, and temporal heterogeneity. Am Nat 110(973):351-369

Nogueira JMM (2003) Fauna living in colonies of Mussismilia hispida (Verrill) (Cnidaria: Scleractinia) in four South-eastern Brazil Islands. Braz Arch Biol Technol 46(3):421-432

Nogueira MM, Menezes NM, Johnsson R, Neves E (2014) The adverse effects of cryptochirid crabs (Decapoda: Brachyura) on Siderastrea stellata Verril, 1868 (Anthozoa: Scleractinia): causes and consequences of cavity establishment. Cah Biol Mar 55(2): $155-162$

Pérez CD, Vila-Nova DA, Santos AM (2005) Associated community with the zoanthid Palythoa caribaeorum (Duchassaing \& Michelotti, 1860) (Cnidaria, Anthozoa) from littoral of Pernambuco, Brazil. Hydrobiologia 548:207-215

Piko AA, Szedlmayer ST (2007) Effects of habitat complexity and predator exclusion on the abundance of juvenile red snapper. J Fish Biol 70:758-769

Ribeiro SM, Omena EP, Muricy G (2003) Macrofauna associated to Mycale microsigmatosa (Porifera, Demospongiae) in Rio de Janeiro State, SE Brazil. Estuar Coast Shelf Sci 57:951-959

Stachowicz JJ, Hay ME (1999) Mutualism and coral persistence: the role of herbivore resistance to algal chemical defense. Ecology 80(6):2085-2101

Stella JS, Pratchett MS, Hutchings PA, Jones GP (2011) Coralassociated invertebrates diversity, ecological importance and vulnerability to disturbance. Oceanogr Mar Biol 49:43-104

Tews J, Brose U, Grimm V, Tielbörger K, Wichmann MC, Schwager M, Jeltsch F (2004) Animal species diversity driven by habitat heterogeneity/diversity: the importance of keystone structures. J Biogeogr 31:79-92

Vytopil E, Willis BL (2001) Epifaunal community structure in Acropora spp. (Scleractinia) on the Great Barrier Reef: implications of coral morphology and habitat complexity. Coral Reefs 20:281-288

Young PS (1986) Análise qualitative e quantitative da fauna associada a corais hermatípicos (Coelenterata, Scleractinia) nos recifes de João Pessoa, PB. Rev Bras Biol 46(1):99-126 